\title{
Meetings and Courses Calendar
}

The following announcements for a conference or a course might be of interest to the readers of this journal. For a new meeting to be listed, sent the information including e-mail addresses or URLs to:

\author{
Subrata Saha, Ph.D. \\ Editor-in-Chief, Journal of Long Term Effects of Medical Implants \\ Dir., Biomed. Eng. Prog., School of Graduate Studies \\ Res. Prof. \& Dir., Musculoskeletal Res. \\ Dept. of Orthopaedic Surg. \& Rehabilitation Med. \\ SUNY Downstate Medical Center \\ 450 Clarkson Avenue - Box 30 \\ Brooklyn, New York 11203 \\ E-mail: subrata.saha@downstate.edu
}

\section{JULY 2010}

July 14-17, 2010

88th General Session \& Exhibition of the IADR

5th General Session of the Pan European Region

of the IADR

Barcelona, Spain

Web: http://www.iadr.org/iags

July 15-17, 2010

8th Trauma 101 Fracture Care for the Community

Orthopedist and Orthopaedic Mid-Level

Providers

Belterra Hotel

Florence, IN

Phone: +1513 5582978

Fax: +1 5135585757

E-mail: westca@ucmail.uc.edu

Web: http://med.uc.edu/ortho/

July 25-27, 2010

BIT Life Sciences' 3rd Annual World Congress of Industrial Biotechnology

Qingdao, China

Web: http://www.bit-ibio.com

\section{AUGUST 2010}

August 1-6, 2010

6th World Congress on Biomechanics (WCB)

14th International Conference on Biomedical

Engineering (ICBME)

6th Asia Pacific Conference on Biomechanics
(APBiomech)

Suntec Convention Centre

Singapore

Phone: +65 63564727

Fax: +65 63567471

E-mail: confmgr@wcb2010.net

Web: http:/www.wcb2010.net

August 8-13, 2010

International Heat Transfer Conference (IHTC-14)

Omni Shoreham Hotel

Washington, DC

Web: http://www.asmeconferences.org/IHTC14

\section{SEPTEMBER 2010}

September 1-4, 2010

32nd International Annual Conference of the

IEEE Engineering in Medicine and Biology

Society

Sheraton Center Buenos Aires

Argentina

Web: http://www.biomedicalimaging.org

September 8-11, 2010

The European Society of Regional Anaesthesia \&

Pain Therapy

XXIX annual ESRA Congress

Porto, Portugal

Web: http://www.kenes.com/esra 
September 12-17, 2010

12th Meeting of the combined Orthopaedic

Associations

Glasgow, Scottland

Web: http://www.comoc2010.org

September 15-19, 2010

14th International Biotechnology Symposium

(IBS) and Exhibition

Biotechnology for the Sustainability of Human

Society

Palacongressi, Rimini, Italy

Phone: +390541 305869

Fax: +390541305842

E-mail: ibs2010@adriacongrex.it

Web: http://www.ibs2010.org

September 20-21, 2010

ASME 5th Frontiers in Biomedical Devices

Conference \& Exhibition

Island Hotel

Newport Beach, CA

E-mail: jakubowskim@asme.org

Web: http://www.asmeconferences.org/

BioMed2010

\section{OCTOBER 2010}

October 1-3, 2010

Allegheny General Hospital Presents: The Nuts and Bolts of General Orthopaedics

The Ritz-Carlton of Naple

Web: http://www.aghcme.org

October 8-12, 2010

ASBMR 32nd Annual Meeting

Metro Toronto Convention Center

Toronto, Ontario, Canada

Web: http://www.asbmr.org/meeting/

meetingsindex.cfm

October 6-9, 2010

ISTA 2010 23rd Annual Congress of the

International Society for Technology in Arthroplasty

Intercontinental Hotel - Festival City

Dubai, United Arab Emirates

Web: www.ISTAonline.org
October 14-15, 2010

25th Annual Research Meeting of the Japanese

Orthopaedic Association

Kyoto International Conference Center

Kyoto, Japan

Phone: +81-3-5216-5551

Fax: +81-3-5216-5552

E-mail: joar2010@congre.co.jp

Web: http://www.congre.co.jp/kiso2010/

October 15-19, 2010

ASBMR 2010 Annual Meeting - Making

Connections in Bone Research

Metro Toronto Convention Centre

Toronto, Ontario, Canada

Web: http://www.asbmr.org

October 16-20, 2010

7th Combined Meeting of Orthopaedic Research

Societies

Kyoto, Japan

Fax: +81529306146

E-mail: cors2010@cs-oto-com

Web: http://www.cs-oto-com/cors2010/

\section{NOVEMBER 2010}

November 7-12, 2010

10th in 2010 International Conference on the

Chemistry and Biology of Mineralized Tissues

Scottsdale, Arizona

Web: http://www.iccbmt.org

\section{APRIL 2011}

April 29 - May 1, 2011

6th World Congress

World Institute of Pain

Seoul, South Korea

Phone: +41229080488

Fax: +41 229069140

E-mail: wip@kenes.com

Web: http://www.kenes.com/wip

\section{MAY 2011}

May 16-20, 2011

CLAIB V Latin American Congress on 
Biomedical Engineering

Cuba

Website will be launched soon

\section{JUNE 2011}

June 14-17, 2011

NBC 15th Nordic-Baltic Conference on

Biomedical Engineering

Aalborg, Denmark

Website will be launched soon

June 22-26, 2011

APCMBE 8th Asian-Pacific Conference on Medical and Biological Engineering

Kuala Lumpur, Malaysia

Website will be launched soon

\section{SEPTEMBER 2011}

September 14-17, 2011

European Conference of the International

Federation for Medical and Biological

Engineering

Budapest, Hungary

Web: http://www.embec2011.com

September 16-20, 2011

ASBMR 33rd Annual Meeting

San Diego, California

Web: http://www.asbmr.org/meeting/meetingsindex.cfm 


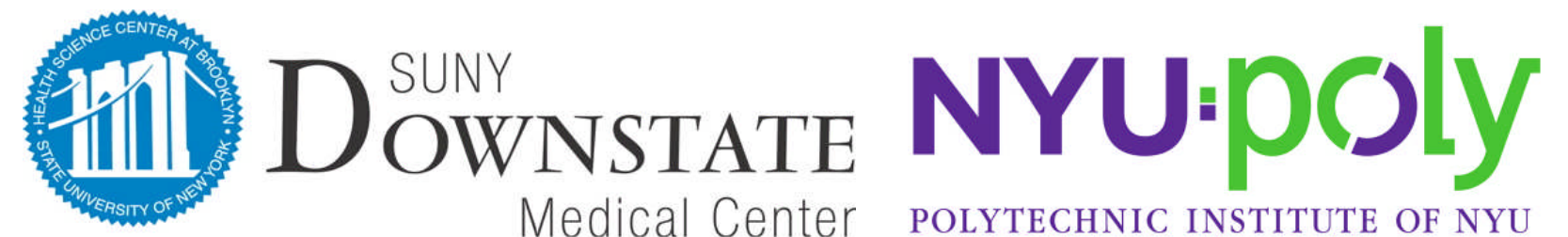

PRELIMINARY CALL FOR ABSTRACTS

\title{
SIXTH INTERNATIONAL CONFERENCE ON ETHICAL ISSUES IN BIOMEDICAL ENGINEERING APRIL 1 - 3, 2011
}

\author{
Website - http://www.downstate.edu/grad/bioethics2011.html \\ http://www.poly.edu/graduate/bioethics2011/
}

CONFERENCE SITE - Polytechnic Institute of NYU FIVE METROTECH CENTER, BROOKLYN, NY 11201

\begin{abstract}
SUGGESTED TOPICS FOR PRESENTATIONS
Animal Testing for Medical DeVices CODE OF ETHICS FOR BIOENGINEERS ETHICAL ISSUES IN CLINICAL ENGINEERING ETHICAL ISSUES IN TISSUE ENGINEERING ETHICS OF NANOBIOTECHNOLOGY MARKETING \& REGULATION OF IMPLANTS \& DEVICE PRIVACY AND BIOINFORMATICS CliniCAL TRIALS OF BIOMEDICAL DEVICES \& IMPLANTS ETHICAL ISSUES IN BIOMEDICAL RESEARCH ETHICAL ISSUES IN DENTISTRY ETHICS OF GENETIC ENGINEERING AND CLONING ETHICS OF STEM CELL USE \& RESEARCH MEDICAL LIABILITY REFORM
\end{abstract}

\section{ABSTRACT SUBMISSIONS}

Abstract submission deadline

Notification of abstract acceptance January 5, 2011 February 5, 2011

Abstracts of all accepted papers from the conference will be published in a special issue of the Ethics in Biology, Engineering and Medicine, An International Journal that will be distributed at the conference.

\begin{tabular}{lcc} 
& \multicolumn{2}{c}{ REGISTRATION FEES } \\
\cline { 2 - 3 } Registration Fee* $^{*}$ & Before March 1st, 2011 & After March 1st, 2011 \\
One-day registration (does not include banquet) & $\$ 150.00$ & $\$ 200.00$ \\
Student registration* $^{*}$ & $\$ 700.00$ & $\$ 150.00$ \\
Guest Banquet Ticket & $\$ 50.00$ & $\$ 90.00$ \\
& $\$ 50.00$
\end{tabular}

${ }^{*}$ Members of co-sponsoring societies, and faculty and students of co-sponsoring universities will receive a $20 \%$ reduction in the registration fees.

Send 200-300 word abstract electronic and hardcopy to:

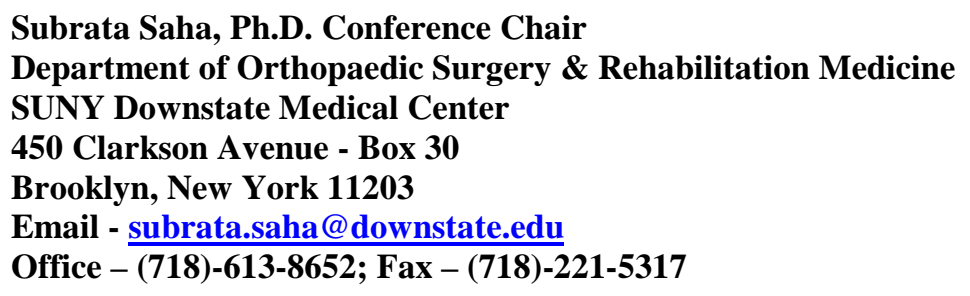




\section{Program Highlights and Themes}

\section{\ Keynote Speakers:}

George Bugliarello, Ph.D.

Polytechnic Institute of NYU

Janice Graham, Ph.D.

Dalhousie University

\section{Invited Speakers:}

Kenneth R. Foster, Ph.D.

University of Pennsylvania

George Khushf, Ph.D.

University of South Carolina

Daniel Vallero, Ph.D.

Duke University

\section{$\checkmark$ Panel Discussions: \\ - Regulation and Reimbursement for Medical Devices}

- Special Symposium:

Ethical Issues in Dentistry

- Rehabilitation Engineering \& Medicine: Ethical Challenges

Co-Sponsors / Endorsements

American Institute of Medical and Biological Engineering (AIMBE)

International Federation for Medical and Biological Engineering (IFMBE)

The New York Academy of Sciences (NYAS)

Additional co-sponsoring societies and institutions will be announced later

\section{American InSTITUTe For Medical.} and Biological Engineering
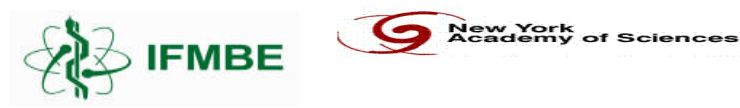

\section{ABSTRACT FORMAT}

An approximately 200-300 word single spaced abstract, text only (no figures, photographs or tables), should be typed in font size 12 using Microsoft Word. It should be right and left justified and typed on 8 $1 / 2 \times 11$-inch paper with one-inch margins. The preferred way is to E-mail your abstract, followed with a hard copy. In your cover letter please identify the corresponding author with complete mailing address, telephone number and E-mail address. Names of additional co-sponsoring institutions \& societies will be included in the final program

\section{HOTEL INFORMATION}

Located within Renaissance Plaza, and across the street from Polytechnic Institute of NYU - located in MetroTech, the New York Marriott at the Brooklyn Bridge is 5 minutes from Manhattan and the Financial District, with 9 major subway lines all within one block. The New York Marriott at the Brooklyn Bridge is the only full service hotel in Brooklyn.

A block of rooms at the Marriott New York at the Brooklyn Bridge have been reserved at a special reduced rate of $\$ 199$ (plus tax) per day for conference attendees during the conference. When calling for reservations mention that you're calling for the " $6^{\text {th }}$ International Ethics Conference" special rate.

Call for Reservations:

Toll Free: (888)-436-3759

Phone: (718)-246-7000

Fax: (718)-222-6520

Website - http://brooklynmarriott.com 